market licences should be allowed; and the romanticised view of alcohol as portrayed in advertisements should be discouraged, and countered by effective health education programmes. Two years ago, shortly after the report of the Royal College of Psychiatrists was published, ${ }^{1}$ we argued that the public health problems associated with excessive drinking were such that fiscal and legislative controls were needed. We concluded: "It remains to be seen whether the Government has the courage to act." This week the Office of Health Economics has argued that the lack of any long-term commitment by the Government to alcohol control is due to fear of losing votes. The current proposals for lifetime banning of alcoholic drivers are a welcome sign of realism, but in March the Chancellor of the Exchequer missed his opportunity to begin a progressive deterrent pricing campaign. Year by year, as politicians prevaricate, the national rise in alcohol consumpttion continues and the damage caused intensifies. How much longer must we wait?

1 Special Committee of the Royal College of Psychiatrists. Alcohol and alcoholism. London: Tavistock Publications, 1979.

2 Young G. Parliamentary written reply. House of Commons Official Report (Hansard) 1980 July 28; 989 :col 448. (No 222.)

3 Office of Population Censuses and Surveys. Hospital In-patient Enquiry 1977. London: HMSO, 1980. (Series MB4, No 10.)

4 Department of Health and Social Security. Health and personal social services statistics for England (with summary tables for Great Britain). London: HMSO, 1978.

5 Saunders JB, Walters JRF, Davis P, Paton A. A 20-year prospective study of cirrhosis. Br Med ₹ 1981 ;282:263-6.

6 Williams GP, Brake GT. Drink in Great Britain 1900-1979. London: Edsall, 1980.

7 Economist Intelligence Unit. Drink in the UK: an analysis of the marketing and distribution of alcoholic beverages. London: Economist Intelligence Unit, 1980.

${ }^{8}$ de Lint J, Schmidt W. The distribution of alcohol consumption in Ontario. Quarterly fournal of Studies on Alcohol 1968 ;29:968-73.

- Cartwright AKJ, Shaw SJ, Spratley TA. The relationships between per capita consumption, drinking patterns and alcohol-related problems in a population sample, 1965-74. Part II : implications for alcohol control policy. $B r F$ Addict 1978;73:247-58.

10 Wilson P. Drinking in England and Wales. London: HMSO, 1980

11 Anonymous. Alcoholism: An inherited disease ? Br Med $\mathcal{f} 1980 ; 281$ : 1301-2.

12 Skog O-J. Quoted by Schmidt W. Cirrhosis and alcohol consumption : an epidemiological perspective. In : Edwards G, Grant M, eds. Alcoholism: new knowledge and new responses. London: Croom Helm, 1977:15-47.

13 Seeley JR. Death by liver cirrhosis and the price of beverage alcohol. Can Med Assoc f $1960 ; 83: 1361-6$.

14 Pequignot G. Les problemes nutritionels de la societe industrielle. La Vie Medicale au Canada Français 1974;3:216-25.

15 Zylam R. Fatal crashes among Michigan youth following reduction of legal drinking age. Quarterly fournal of Studies on Alcohol 1964 ;35:283-6.

16 McGuinnes T. An econometric analysis of total demand for alcoholic beverages in the UK, 1956-75. Edinburgh: Scottish Health Education Unit, 1979.

17 Anonymous. Action on alcohol. Br Med F 1979;i:361-2.

\section{Does cimetidine cause gastric cancer?}

Balancing the safety and efficacy of any drug requires an attempt to weigh factors that are imponderable. Neither the benefits of treatment nor the disadvantages imposed by adverse effects can be measured by any single objective standard. A fear of inducing fetal malformations may be of paramount importance in some cases, while aversion to a drug which may cause cancer will be a central concern in many others.

Cimetidine has now been widely used for four years. It is unquestionably beneficial in promoting healing of peptic ulcers, but it also has proved adverse effects, which include mild antiandrogenic properties, a tendency to cause con- fusion especially when used in high doses and in elderly patients, and modest slowing of hepatic drug metabolism. Generally, the drug's short-term safety record is good, but concern has repeatedly been expressed that treatment might promote the development of gastric cancer, and earlier this year this concern was given prominence in an article in the Sunday Times.

The case against cimetidine may be divided into two parts. Firstly, patients with pernicious anaemia (whose stomachs are achlorhydric) have between two and four times the usual frequency of gastric cancer. Cimetidine induces hypochlorhydria, and case histories have been reported of patients in whom gastric cancer was diagnosed after treatment with cimetidine for peptic ulcer. Secondly, the pathophysiological conditions prevailing in the stomach during treatment with cimetidine have been said to favour the formation of carcinogens either as a general property of the reduction of acidity or else as a result of the specific configuration of the cimetidine molecule. How good is the evidence on each of these points?

The analogy with the stomach of the patient with pernicious anaemia may be poor. Such patients have an autoimmune disorder associated with gastric atrophy, and their liability to develop gastric cancer may well be due in whole or part to the inflammatory process in the gastric wall or to the thinning of the mucosa, which would allow easier access of carcinogenic substances to sites of natural cellular proliferation. Patients with pernicious anaemia have stomachs that are obviously and grossly abnormal; there is no evidence that the stomachs of patients who have received prolonged courses of cimetidine differ materially from the stomachs of those who have not.

Case reports of gastric cancer detected after treatment with cimetidine are few, but they include instances where gastroscopy and biopsy before treatment found no evidence of malignancy and where cancer apparently complicated simple duodenal ulceration, ordinarily a rare occurrence. ${ }^{1-3}$ These reports are disturbing, but the numbers are small, and in none of them might the gastric cancer not have been present before treatment was started. Furthermore, the interval between the start of treatment and the occurrence of cancer was very short-two years or much less. Induction of the common cancers associated with aging is generally believed to take many years. Where gastric cancer is concerned there are few hard data. Nevertheless, migrants from high-risk to low-risk areas for gastric cancer tend to retain the cancer liability of their native population..$^{4}$ Again, a small but distinct increase in the frequency of gastric cancer is a known risk for patients who have had a partial gastrectomy; and, while no precise figure can be attached to the interval between operation and the occurrence of cancer, it is probably above 10 years..$^{5-7}$ One series of cases gave an average interval of 17 years. $^{6}$

Cimetidine treatment partially suppresses secretion of gastric acid, which is likely to favour the formation of nitrosamines-which, in general, are potent carcinogens. Human gastric juice ordinarily contains amines and these might react with nitrite to form nitrosamines. Neutral gastric juice also tends to contain bacteria that can generate nitrite from nitrate, and hence favour nitrosation. Thiocyanates, which would tend to catalyse the reaction, have also been detected in increased quantities in neutral gastric juice. ${ }^{8}$ These findings all need fuller evaluation. On the one hand, exposure to nitrate has been associated with an increased risk of gastric cancer, ${ }^{9-10}$ particularly in South America. On the other hand, if thiocyanate catalysation were important smokers might be expected to be peculiarly prone to gastric cancer, and this is not so. 
Any process of intragastric neutralisation should favour nitrosation. Cimetidine treatment has, as might be expected, been shown to increase the total bacterial counts and the counts of nitrate-reducing organisms in gastric juice. ${ }^{11}$ Total concentrations of nitrosamines in gastric juice have also been reported to rise during treatment with cimetidine. ${ }^{12}$ Unfortunately, newspaper comment on this result preceded the publication of full experimental details, but the increase in total nitrosamine concentration associated with the use of cimetidine does not seem to be any greater than would have been expected during any process of neutralising gastric juices. Furthermore, the concentrations of nitrites in gastric juice were rarely found to be raised, and the incidence of bacterial overgrowth was low in individuals taking a normal diet, ${ }^{13}$ suggesting that the hypochlorhydria seen with treatment with cimetidine does not have the same effects as achlorhydria.

The specific suggestion has been made that the cimetidine molecule itself may be nitrosated and that nitrosocimetidine is capable of alkylating DNA. ${ }^{14-16}$ Experimental evidence available indicates that cimetidine is nitrosatable, but only in the presence of strong hydrochloric acid-for instance, twice molar ${ }^{14}$-which is many times stronger than is found in gastric juice. Furthermore, nitrosocimetidine has not yet been detected in gastric juice. Even if it were the amounts detected would not necessarily be important. If nitrosocimetidine were formed in substantial quantities then prolonged exposure of animals to high doses of cimetidine might be expected to cause gastric cancer, but this has not been found. ${ }^{17} 18$

Taken overall, the clinical evidence linking cimetidine use with liability to gastric cancer is weak; anecdotal case reports are unlikely to supply definitive answers, though long-term prospective follow-up studies of large cohorts of patients who have received the drug may do so. The pathophysiological evidence suggesting that nitrosamines are more likely to be formed when gastric juice is totally neutralised, whether by cimetidine or any other agent, is strong. This has yet to be shown, however, to be a peculiar and important risk of ordinary treatment with cimetidine.

Unfortunately, the part played by mutagenic agents in the processes of carcinogenesis in aging man remains poorly understood. The assumption that mutagens are necessarily carcinogenic and importantly so in man is unsure, contestable, and emotive. ${ }^{1920}$ Debate in the national press about the possible carcinogenicity of cimetidine, or any other drug, which uses results which have yet to be fully reported and where the implications of the findings are unsure does no one a service. Certainly cimetidine, like any other drug, should be used with care and circumspection, both on general grounds of clinical common sense and because experience of long-term usage and its results is necessarily limited; but patients may be reassured.

${ }^{1}$ Elder JB, Ganguli PC, Gillespie TE. Cimetidine and gastric cancer. Lancet 1979 ; i : 1005-6.

2 Reed PI, Cassell PG, Walters CL. Gastric cancer in patients who have taken cimetidine. Lancet 1979 ;i :1234-5.

${ }^{3}$ Hawker PC, Muscroft TJ, Keighley MRB. Gastric cancer after cimetidine in patient with two negative pre-treatment biopsies. Lancet $1980 ; \mathrm{i}$ : 709-10.

Buell P, Dunn JE. Cancer mortality among Japanese Issei and Nisei of California. Cancer 1965;18:656-64.

${ }^{5}$ Eberlein TJ, Lorenzo FV, Webster MW. Gastric carcinoma following operation for peptic ulcer disease. Ann Surg 1978;187:251-6.

6 Taksdal S, Stalsberg H. Histology of gastric carcinoma occurring after gastric surgery for benign conditions. Cancer 1973;32:162-6.

' Schrumpf E, Serck-Hanssen A, Stadaas J, Auhe S, Myren J, Osnes M. Mucosal changes in the gastric stump 20-25 years after partial gastrectomy. Lancet 1977 ;ii:467-9.

${ }^{8}$ Ruddell WSJ, Bone ES, Hill MJ, Blendis LM, Walters CL. Gastricjuice nitrite. A risk factor for cancer in the hypochlorhydric stomach ? Lancet 1976;ii:103-9.
9 Arijo R, Coulson AH. Epidemiology of stomach cancer in Chile-the role of nitrogen fertilizers. Int $\mathcal{f}$ Epidemiol 1975;4:301-9.

${ }^{10}$ Cuello C, Correa P, Haenszel W, et al. Gastric cancer in Colombia. 1. Cancer risk and suspect environmental agents. Fournal of the National Cancer Institute 1976;57:1015-20.

11 Ruddell WSJ, Axon ATR, Findlay JM, Bartholomew BA, Hill MJ. Effect of cimetidine on the gastric bacterial flora. Lancet $1980 ; \mathrm{i}: 672-4$.

12 Reed PI, Smith PLR, Walters CL. The influence of cimetidine treatment on gastric $\mathrm{pH}$ and nitrosamine concentration. Abstracts XI International Congress of Gastroenterology, Hamburg, 1980, 58.

${ }^{13}$ Muscroft TJ, Youngs DJ, Burdon DW, Keighley MRB. Cimetidine is unlikely to increase formation of intragastric $\mathrm{N}$-nitroso-compounds in patients taking a normal diet. Lancet $1981 ; \mathrm{i}: 408-10$.

14 Foster $A B$, Jarman $M$, Manson $D$. Structure and reactivity of nitrocimetidine. Cancer Lett 1980;9:47-52.

${ }^{15}$ Bavin PMG, Durant GJ, Miles PD, Mitchell RC, Pepper ES. Nitrosation of cimetidine. Fournal of Chemical Research 1980; synop, No 6:212-3.

${ }^{16}$ Jensen DE, Magee PN. Methylation of DNA by nitrosocimetidine in vitro. Cancer Res $1981 ; 41: 230-60$

${ }^{17}$ Brimblecombe RW, Duncan WAM, Durant GJ, et al. Characterisation and development of cimetidine as a histamine $\mathrm{H}_{2}$-receptor antagonist. Gastroenterology 1978;74:339-47.

${ }^{18}$ Crean GP, Leslie GB, Roe FJC. Cimetidine and gastric cancer: negative studies in dogs. Lancet 1979;ii:797-8.

19 Peto R. Distorting the epidemiology of cancer: the need for a more balanced overview. Nature 1980;284:297-300.

${ }^{20}$ Cairns J. The origin of human cancers. Nature 1981 ;289:353-7.

\section{Hazards of unemployment}

Unemployment tends to bring a sequence of psychological reactions in its train. At first, shock and disbelief are combined with optimism and a sense of being on holiday; then the holiday feeling gives way to meaningless leisure, inertia, and exhaustion, with a loss of self-esteem and tensions in the family; and lastly comes the "broken state," in which despite the lifting of earlier anxiety and depression there is a feeling of inferiority, submissiveness, and inability to provide for needs, with acceptance of the new "non-occupational" identity, a more limited way of life, and little hope of change. ${ }^{1}$ This important and topical theme was developed in a recent lecture by Professor W Linford Rees, the highlight of a BMA symposium in Southampton on the hazards of the working environment (see $\mathrm{p}$ 1247).

Continuing unemployment, then, has an enduring effect on the personality. It is also associated with increased rates of both mental and physical illness. For example, Brenner found increased death rates from heart and kidney disease, cirrhosis, and homicides and more admissions to mental hospitals and prison sentences among the unemployed; and it was not those with previous mental disorder and hospital admissions who accounted for the increases. ${ }^{2}$ Moreover, in both the United States and Britain the rate of unemployment and the state of the economy have been correlated with various measures of mental and physical ill health; and those affected also appear to be more vulnerable to chronic disease processes, notably of the cardiovascular system.

The link between unemployment and psychological and social ill effects is obvious. Even so, the strength of the effects may not be widely enough recognised; a group of unemployed people were found to be similar to patients suffering from mixed neurotic disorders, with much higher levels of anxiety, guilt, hostility, self-criticism, and distress than normal. Physical ill effects may be even less well appreciated but they too are entirely comprehensible if unemployment (and indeed subsequent employment in new and perhaps unfamiliar work) is regarded as a stress that taxes a person's adaptive ability. The results of a prospective longitudinal study in the United States, starting when a firm was about to close down, were 